\title{
Tetracycline and viruses: a possible treatment for COVID-19?
}

\author{
Jesús A. Mosquera-Sulbaran ${ }^{1}\left[\right.$ - Hugo Hernández-Fonseca ${ }^{2,3}$ \\ Received: 22 June 2020 / Accepted: 13 September 2020 / Published online: 2 November 2020 \\ (c) Springer-Verlag GmbH Austria, part of Springer Nature 2020
}

\begin{abstract}
Tetracyclines have been used to treat many bacterial infections. The use of these antibiotics for the treatment of viral diseases dates to the 1960s to 1970s. Over the decades, the effect of tetracyclines on the pathogenesis of viral infections has been demonstrated both clinically and experimentally. Tetracyclines can act on viral infections either through their antibacterial properties or through direct antiviral action. This review focuses on clinical and experimental data that support the use of tetracycline in treating viral infections and highlights an important approach to slowing disease progression during viral infections. Tetracycline treatment might represent a strategy for eliminating the infection or inhibiting the progression of COVID-19.
\end{abstract}

\section{Introduction}

Tetracyclines are broad-spectrum antibiotics [1] that are synthesized by modifying natural tetracycline to form several new compounds. Among these compounds, called semi-synthetic tetracyclines, are doxycycline (Dox) and minocycline (Min). Minocycline (a second-generation tetracycline) acts on Gram-negative and Gram-positive bacteria and is used to treat various types of infections (respiratory tract, skin, urethritis, gonorrhea, anthrax, meningococcal infections, and chlamydial infections) $[2,3]$. The size of minocycline (495 Da) and its lipophilic nature allow it to cross the bloodbrain barrier more easily than doxycycline and other tetracyclines $[4,5]$. Therefore, it has been used to treat various neurological disorders [6-9]. Doxycycline also has a wide range of antimicrobial $[10,11]$ and anti-inflammatory $[12$,

Handling Editor: YiMing Shao.

Jesús A. Mosquera-Sulbaran

mosquera99ve@yahoo.com

Hugo Hernández-Fonseca

hjhfonseca@gmail.com

1 Facultad de Medicina, Instituto de Investigaciones Clínicas "Dr. Américo Negrette", Universidad del Zulia, Apartado Postal: 23, Maracaibo 4001-A, Zulia, Venezuela

2 Facultad de Ciencias Veterinarias, Universidad del Zulia, Maracaibo, Venezuela

3 Present Address: Anatomy, Physiology and Pharmacology Department, School of Veterinary Medicine, Saint George's University, Saint George's, Grenada
13] properties and is used to treat a variety of infections (anthrax, chlamydial infections, pneumonia, Lyme disease, cholera, syphilis, and others) [14]. The use of tetracyclines as antiviral agents dates to the 1960s and 1970s, and over the decades, they have shown an antiviral effect both experimentally and clinically. The aim of this review was to report on the different antiviral effects of tetracyclines and to highlight their possible beneficial effect on the treatment of COVID19. In this regard, a literature review was performed. Published studies were identified through citation chasing, a search of PubMed and Google Scholar using the systematic review methods filter, and the authors' topical knowledge.

\section{Effects and properties of tetracyclines}

Tetracyclines act through their binding to the bacterial ribosome at high- and low-affinity sites (30S and 50S) and blocking protein synthesis $[15,16]$. Allosteric binding of tetracyclines to the ribosome inhibits the binding of aminoacyl-tRNAs at the acceptor site, thus inhibiting protein synthesis [17].

Tetracyclines have other properties besides their antibacterial activity. These antibiotics can inhibit metalloproteinase (MMP) endopeptidases, which are zinc-dependent enzymes that are important in several physiological and pathological processes, including embryogenesis, tissue remodeling, inflammation, and the metastatic action of tumors [18-20]. The mechanism of action of tetracyclines on MMP is not known; however, it has been suggested that 
they have a direct action on metalloproteinase, preventing its expression [21].

Tetracyclines also can act on reactive oxygen species (ROS). The increase in ROS induces oxidative stress during pathological conditions that can lead to the destruction or dysfunction of various cellular components. Reactive oxygen species are formed by the superoxide anion $\left(\mathrm{O}_{2}^{-}\right)$, the hydroxyl radical $\left(\mathrm{OH}^{-}\right)$, the non-free-radical hydrogen peroxide $\left(\mathrm{H}_{2} \mathrm{O}_{2}\right)$, hypochlorite $(\mathrm{HOCl})$, and peroxynitrite $\left(\mathrm{ONOO}^{-}\right)$[22]. Dox, Min, and other tetracyclines have a phenolic ring, which can bind to these radicals and eliminate them, leaving a stable, non-reactive phenolic radical [23].

Tetracyclines also have antiapoptotic effects. Caspases are a family of cysteine proteases that activate the apoptosis cascade. After activation of initiator caspases, downstream executioner caspase activation takes place, leading to cellular destruction (apoptosis). Activation of caspases can occur either by external stimulation (death receptor) or by internal stimulation (mitochondrial). Ligands such as TNF- $\alpha$ and Fas, after interaction with cell surface receptor, induce a signal transduction cascade leading to caspase- 8 activation, which activates caspase-3. In the intrinsic pathway, the mitochondria are stimulated by internal and external stimuli leading to mitochondrial alterations and resulting in the release of pro-apoptotic factors. These mitochondrial alterations are represented by increased mitochondrial permeability with water influx, inducing mitochondrial swelling and outflow of pro-apoptotic factors such as cytochrome C, Smac/DIABLO, and apoptosis-inducing factor (AIF). These factors activate caspase-9 (cytochrome C), inhibit caspase inhibitors (Smac/DIABLO), and induce DNA fragmentation (AIF). The induction of apoptosis by mitochondria is regulated by pro-apoptotic (Bax, Bad, Bid) and anti-apoptotic (Bcl-2, Bcl-xL) proteins. In these ways, the sequential activation of caspases induces apoptosis [24-26]. Due to their antiapoptotic action, both Min and Dox have a protective role in various neurological disorders. This neuroprotection is related to a reduction in the expression of caspase- 1 and/ or caspase-3 [27-30]. Min also acts by inhibiting the mitochondrial release of cytochrome C, Smac/DIABLO, and AIF in cell culture and in a mouse model of Huntington's disease [31]. In this regard, the anti-apoptotic capacity of Min and Dox is demonstrated by their ability to inhibit caspases and induce mitochondrial stabilization [21] (Fig. 1).

Another property of tetracyclines is their potential antiinflammatory capability. Tetracyclines can be anti-proteolytic agents and ROS inhibitors and are therefore likely to exert an anti-inflammatory effect. Tetracyclines are associated with inhibition of pro-inflammatory cytokines, and MMP and ROS levels, and both Min and Dox can inhibit enzymes such as pancreatic and non-pancreatic phospholipase A2, which are involved in inflammatory processes [32]. Leukocyte migration is critical for inflammatory processes to occur. Tetracyclines can inhibit neutrophil migration [33], as well as leukocyte adhesion [34] and lymphocyte proliferation [35]. Many of the anti-inflammatory effects of tetracyclines are related to their ability to inhibit the functions of the NF- $\kappa B$ transcription factor. In this regard, Min

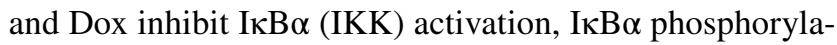
tion and degradation and $\mathrm{p} 65$ and nuclear translocation of NF- $\mathrm{KB}[36,37]$. However, other pathways, such as the p38 and ERK1/2/MAPK pathways, can be modulated by the antiinflammatory effects of Min and Dox [37] (Fig. 2).

\section{Tetracyclines as antiviral agents}

The study of tetracyclines as antiviral agents opens an interesting field in microbiological therapy. The first available report on the antiviral activity of tetracycline came when
Fig. 1 Anti-apoptotic properties of minocycline (Min), which has the potential to suppress apoptotic signals in cells. By acting on the extrinsic pathway of apoptosis activation, Min can inhibit the activation of caspase-7, a caspase with pro-apoptotic activity. In the intrinsic pathway of apoptosis activation, Min can inhibit oligomerization of pro-apoptotic mitochondrial proteins (Bax/Bak) and the export of cytochrome C and Smac/Diablo, blocking activation of caspase 9 and its effect on caspase 3activation. Min also blocks the apoptotic effect of caspase 3

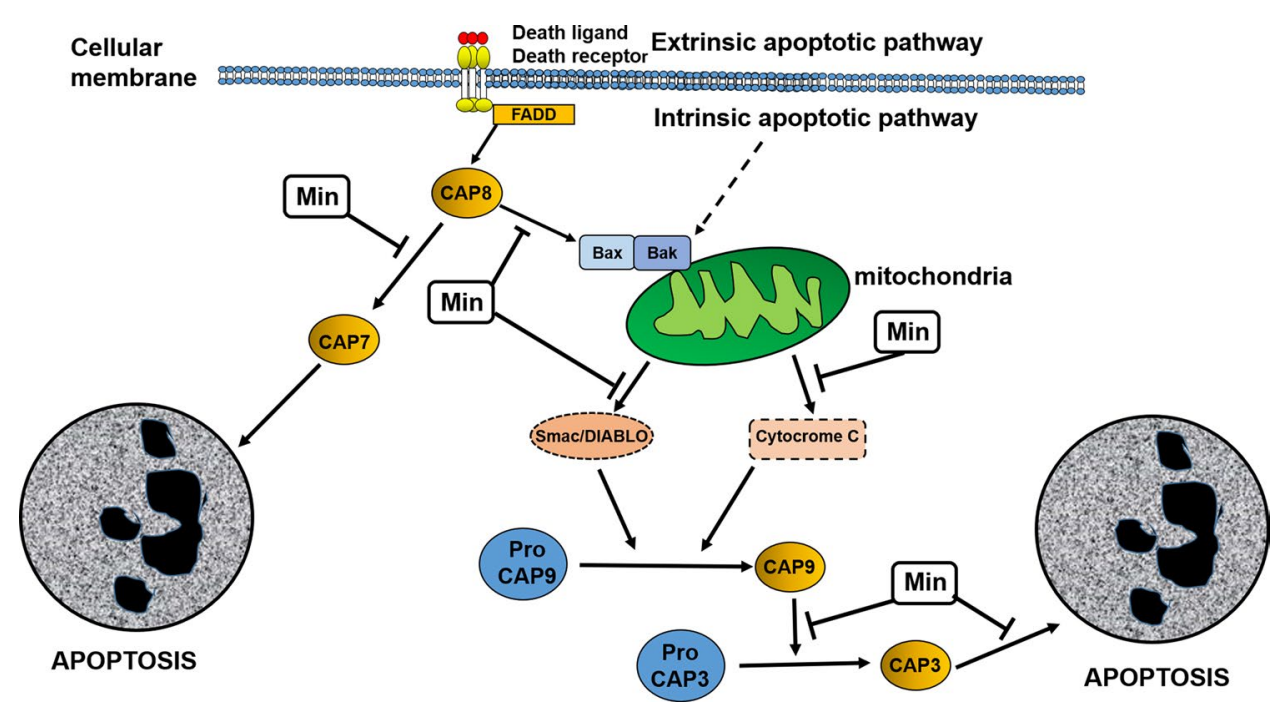


Fig. 2 Effect of tetracyclines on the NF- $\mathrm{kB}$ transcription factor pathway. Minocycline (Min) and doxycycline (Dox) are capable of inhibiting the NF- $\kappa \mathrm{B}$ pathway, acting on different points of this activation by inhibiting I $\mathrm{B} \alpha \alpha(\mathrm{IKK})$ activation, I $\mathrm{K} \mathrm{B} \alpha$ phosphorylation, degradation and p65, and nuclear translocation of NF- $\mathrm{NB}$, leading to a decreased proinflammatory immune response

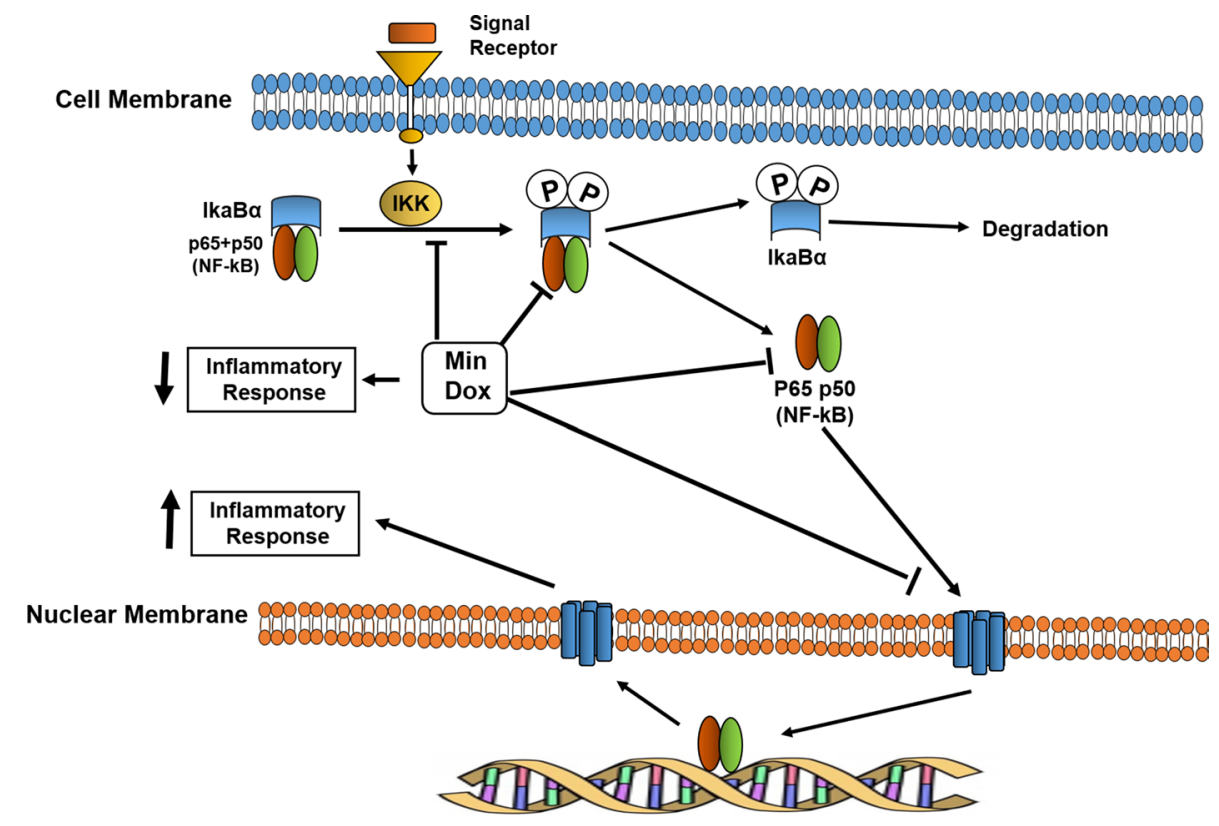

Negrette et al. reported, between 1960 and 1970, that tetracyclines provide protection against several viruses. In this regard, clinical experience demonstrated the beneficial role of tetracycline in epidemics of Venezuelan equine encephalitis (VEE) virus and infectious mononucleosis (Maracaibo, Venezuela), as well as in other viral conditions [38-44]. Tetracyclines also showed a high protective effect in mice and chicken embryos infected by VEE virus $[45,46]$. These findings were reported at a time when the use of antibiotics for the treatment of viral diseases was unknown.

In recent decades, Min and Dox and other tetracycline compounds have been extensively studied for their antiviral activity. Lemaitre et al [47] reported that Min and Dox had a protective effect against the human immunodeficiency virus (HIV) by preventing the cytopathic effects of the virus on human lymphoblastic T cells. Other studies showed that inhibition of the microglia by Min in cell culture reduced the production of HIV by those cells [48]. In a simian immunodeficiency virus (SIV) model, Min reduced the severity of encephalitis, brain viral load, and expression of brain inflammatory markers. In addition, Min inhibited SIV replication in vitro [49]. These protective effects were mediated by suppression of p38MAPK and JNK levels in the brain, which inhibit the kinase-regulated apoptosis signal (ASK1) [50]. In addition, Min has affinity for HIV-1 integrase [51], inhibiting the integration of viral DNA into the host genome.

Min is also effective against flavivirus infections. This antibiotic inhibited West Nile virus (WNV) replication in cultured human neural cells, preventing virus-induced apoptosis [52]. In experimental infection with Japanese encephalitis virus (JEV) in mice, Min reduced neuronal apoptosis, microglial activation, caspase activation, production of brain proinflammatory mediators, and viral replication [53]. Macrophage migration inhibitory factor (MIF) facilitates dengue virus replication by inducing autophagy. Treatment with Min decreased the viral load, MIF secretion, and autophagy, and increased survival in dengue-virus-infected mice [54]. In other studies, Min was shown to induce the expression of genes associated with anti-inflammatory activation (M2) in the microglia while it inhibited the expression of genes associated with pro-inflammatory activation (M1) in WNVinfected mice, reducing cytotoxicity in response to WNV [55]. Min also confers protection against alphavirus infection in animal models by inhibiting microglial activation and decreasing production of interleukin-1-beta in the central nervous system [56]. In VEE virus-infected mice, Min decreased viral replication, nitric oxide production, and lipid peroxidation in the brain and in cultures of virus-infected neuroblastoma [57]. Min reduced the cytopathic effect mediated by respiratory syncytial virus and prevented infection by this virus [58]. Min is an antiviral agent in mice infected by enterovirus 71 , reducing the expression of cytokines and viral replication. In addition, Min reduced the cytopathic effect in THP-1 cell cultures infected with enterovirus 71 [59]. Crimean-Congo hemorrhagic fever virus is a member of a family of hemorrhagic fever viruses, and its nucleoprotein is a key protein in virus replication. Min and Dox can inhibit this protein, slowing viral replication [60].

Dox has also shown antiviral activity. Recent studies have demonstrated the importance of the p53 protein in the host antiviral response against several viruses, including vesicular stomatitis virus (VSV) [61] and influenza virus [62]. The ability of Dox to induce p53 probably extends the antiviral effect of this antibiotic. In this regard, the inhibition of p53 
expression by JEV in H1299 cell cultures was inhibited by Dox $[63,64]$. Dox also inhibited the cytopathic effect and viral replication in H1299 cell cultures infected by VSV [64]. This antibiotic significantly reduced the cytopathic effect and viral replication in Marc-145 cells infected by swine respiratory syndrome virus [65]. Dox also reduced the severity of acute lung injury in mice infected with influenza H3N2 virus [66]. The antiviral effect of Dox against flaviviruses has also been reported. In vitro studies have shown that Dox prevents the entry and replication of chikungunya virus in Vero cell cultures [67]. Dox also inhibited the serine protease of dengue virus (DENV NS2B-NS3pro), inhibiting the entry and replication of four dengue serotypes (DENV2, DENV4, DENV1 and DENV3) in Vero cell cultures [68, 69]. In addition to this mechanism, Dox, through its tetracyclic rings, can alter the conformation of the dengue virus envelope protein and block the entry of this virus into the cells [70] (Fig. 3).

Viral resistance to tetracycline could be a problem in tetracycline treatment. Antibiotic resistance occurs when germs like bacteria and fungi develop the ability to defeat the drugs designed to kill them. Tetracycline resistance is widespread among Gram-positive and Gram-negative bacteria and can be the result of pumping the drug out of the cell before it reaches its site of action (efflux), protection of the ribosomal

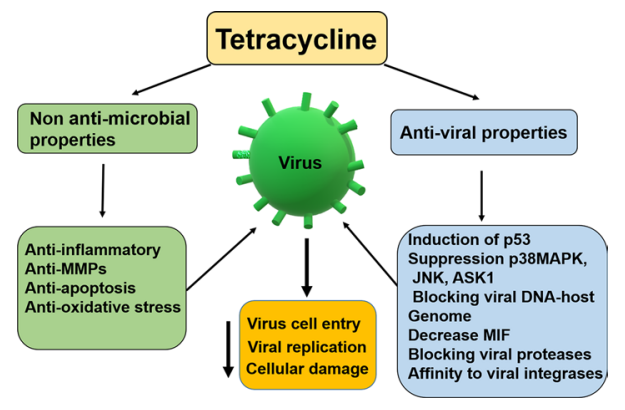

Fig. 3 Effect of tetracyclines on viral pathogenesis. Tetracyclines can affect the viral life cycle by indirect and direct mechanisms. Indirect effects are based on anti-apoptotic, anti-metalloproteinase (MMPs), anti-oxidative stress, and anti-inflammatory properties of these compounds. Different mechanisms of antiviral activity of tetracyclines have been reported. Overall, the properties of tetracycline by acting on viral pathogenesis leads to decreased entry of the virus into the host cell, decreasing its replication and cellular damage. MIF, macrophage inhibitory factor binding site, which decreases drug binding, or changes in the permeability of the cell envelope that reduce drug uptake [71]. Viruses are not living particles; they need host cells to replicate. The antiviral effect of tetracyclines is indirect and involves several mechanisms that the viruses use to enter and replicate cells. The blockage of protein synthesis in the cell by tetracyclines might inhibit virion formation. Thus, it is unlikely that the mechanisms of antibiotic resistance used by viruses will be similar to those used by bacteria is unlikely.

\section{COVID-19 and tetracyclines}

A new severe acute respiratory syndrome coronavirus (SARS-CoV-2) causing coronavirus disease 2019 (COVID19) emerged in Wuhan, China, in December 2019 [1]. Currently there is a race against time to identify therapeutic treatments for COVID-19. SARS-CoV-2 is a new emerging zoonotic coronavirus belonging to the same viral family as the viruses that cause SARS (severe acute respiratory syndrome) and MERS (Middle East respiratory syndrome). Tetracyclines (e.g., tetracycline, halogenated tetracyclines, doxycycline, and minocycline) are highly lipophilic antibiotics that are known to chelate zinc compounds on matrix metalloproteinases (MMPs). Several functions of coronavirus are associated with the host MMPs complex, including replication $[72,73]$. Therefore, the zinc-chelating properties of tetracyclines may also aid in inhibiting SARS-CoV-2 infections in humans, limiting their ability to replicate within the host. Tetracyclines might also be able to inhibit RNA replication of positive-sense single-stranded RNA viruses [69], like SARS-CoV-2, and they can downregulate the NF- $\mathrm{kB}$ pathway, decreasing the levels of inflammatory cytokines such as TNF- $\alpha$, IL- $1 \beta$, and IL-6 induced by SARS-CoV- 2 . In addition, tetracyclines stand out as potential inhibitors of the main protease of SARS-CoV-2 [74] (Fig. 4). In this context, various investigators have suggested the use of tetracyclines as potential therapeutic agents for the treatment of COVID-19 [74-76].

The effect of tetracyclines on apoptosis in relation to their antiviral activity may be controversial in the context the virus type and the stage of cellular infection. As described above, tetracyclines can inhibit apoptosis but they can also induce apoptosis $[77,78]$. A interesting point regarding
Fig. 4 Potential effects of tetracyclines on SARS-CoV-2. Several properties of tetracyclines can potentially decrease the ability of SARS-CoV-2 to enter and reproduce in the cell
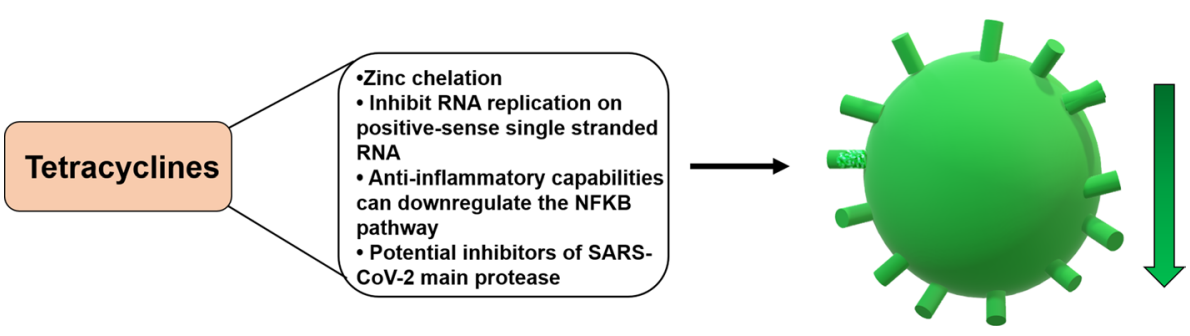
apoptosis is that a cell invaded by a virus needs to be eliminated by the organism as an infected cell, using various mechanisms, including the antiviral immune response [79], but the virus requires a living cell for reproduction, and in the late period of infection can use apoptosis as a means of breaking the cell and increasing the spread of the virus [79]. Therefore, the antiviral effect of tetracyclines on apoptosis may be related to the spread of infection. When tetracyclines induce apoptosis [77, 78], they can favor the dissemination of the virus, but at the same time decrease its replication, but when tetracyclines block apoptosis [27-31], they can decrease spread of the virus. It has been reported that SARSCoV-2 induces apoptosis in infected cells [80], and the effect on this process of tetracycline remains unknown.

Although several studies have shown that tetracyclines have antiviral and anti-inflammatory effects, all of them have been in vitro studies using experimental models. There are still no final results of clinical studies demonstrating the efficacy of these antibiotics for treatment of patients with COVID-19. There has been only one phase 2 study in which doxycycline was used together with ivermectin for the treatment of COVID-19 patients [81]. However, the potential of tetracyclines as an antiviral drug is high and requires further clinical studies. It is important to develop antiviral treatments for COVID-19 that can be administered early in infection in order to avoid the organ damage caused by the virus and allow the patient to produce a strong immune response against the virus. Therapeutic interventions in patients with severe organ damage caused by the virus or by an excessive immune response may have little effect on eliminating the virus or the recovery of the patient when antiviral strategies are given at later times.

\section{Conclusion}

Experimental studies have shown that the antiviral effects of tetracyclines are based on their anti-apoptotic and antiinflammatory activities and on direct effect on viral biology, leading to inhibition of viral entry and viral replication. These studies highlight an important and fruitful approach in antiviral drug research. The early use of tetracyclines in COVID-19 could have a beneficial effect, preventing the viral infection from progressing to more serious stages that can lead to death in individuals infected with SARS-CoV-2.

Author contributions JM and HHF selected the topic, initiated the project, conceptualized the ideas, and drafted the manuscript. All authors contributed to literature search, analysis, interpretation, and manuscript preparation. All authors have critically reviewed, discussed, and approved all the content of the manuscript for publication.

Funding This study received no financial support.

\section{Compliance with ethical standard}

Conflict of interest No potential conflict of interest is reported by the authors.

\section{References}

1. Duggar BM (1948) Aureomycin: a product of the continuing search for new antibiotics. Ann NY Acad Sci 51:177-181. https ://doi.org/10.1111/j.1749-6632.1948.tb27262.x

2. Goulden V (2003) Guidelines for the management of acne vulgaris in adolescents. Paediatr Drugs 5:301-313. https://doi. org/10.2165/00128072-200305050-00003

3. Smilack JD (1999) The tetracyclines. Mayo Clin Proc 74:727-729. https://doi.org/10.4065/74.7.727

4. Macdonald H, Kelly RG, Allen ES, Noble JF, Kanegis LA (1973) Pharmacokinetic studies on minocycline in man. Clin Pharmacol Ther 14:852-861. https://doi.org/10.1002/cpt1973145852

5. Carney S, Butcher RA, Dawborn JK, Pattison G (1974) Minocycline excretion and distribution in relation to renal function in man. Clin Exp Pharmacol Physiol 1:299-308. https://doi. org/10.1111/j.1440-1681.1974.tb00552.x

6. Gordon PH, Moore DH, Miller RG, Florence JM, Verheijde JL, Doorish C (2007) Efficacy of minocycline in patients with amyotrophic lateral sclerosis: a phase III randomised trial. Lancet Neurol 6:1045-1053. https://doi.org/10.1016/S1474-4422(07)70270 $-3$

7. Lampl Y, Boaz M, Gilad R, Lorberboym M, Dabby R, Rapoport A (2007) Minocycline treatment in acute stroke: an open-label, evaluator-blinded study. Neurology 69:1404-1410. https://doi. org/10.1212/01.wnl.0000277487.04281.db

8. Thomas M, Le WD (2004) Minocycline: neuroprotective mechanisms in Parkinson's disease. Curr Pharm Des 10:679-686. https ://doi.org/10.2174/1381612043453162

9. Zabad RK, Metz LM, Todoruk TR, Zhang Y, Mitchell JR, Yeung M (2007) The clinical response to minocycline in multiple sclerosis is accompanied by beneficial immune changes: a pilot study. Mult Scler 13:517-526. https://doi.org/10.1177/1352458506 070319

10. Michalopoulos A (1973) A clinical and laboratory study of doxycycline ('Vibramycin'): a broad-spectrum antibiotic. Curr Med Res Opin 1:445-455. https://doi.org/10.1185/030079973091117 06

11. Pulverer G (1969) Doxycycline-a broad spectrum antibiotic of the tetracycline series. Med Klin 64:1033-1037

12. Krakauer T, Buckley M (2003) Doxycycline is anti-inflammatory and inhibits staphylococcal exotoxin-induced cytokines and chemokines. Antimicrob Agents Chem 47:3630-3633. https://doi. org/10.1128/aac.47.11.3630-3633.2003

13. Cazalis J, Bodet C, Gagnon G (2008) Doxycycline reduces lipopolysaccharide-induced inflammatory mediator secretion in macrophage and ex vivo human whole blood models. J Periodontol 79:1762-1768. https://doi.org/10.1902/jop.2008.080051

14. Joshi NJ, Miller D (1997) Doxycycline revisited. Arch Intern Med 157:1421-1428

15. Hash JH, Wishnick M, Miller PA (1964) On the mode of action of the tetracycline antibiotics in Staphylococcus aureus. J Biol Chem 239:2070-2078

16. Tritton TR (1977) Ribosome-tetracycline interactions. Biochemistry 16:4133-4138. https://doi.org/10.1021/bi00637a029

17. Semenkov YP, Makarov EM, Makhno VI, Kirillov SV (1982) Kinetic aspects of tetracycline action on the acceptor (A) site of 
Escherichia coli ribosomes. FEBS Lett 144:125-129. https://doi. org/10.1016/0014-5793(82)80584-x

18. Rohde LE, Ducharme A, Arroyo LH, Aikawa M, Sukhova GH, Lopez-Anaya A, McClure KF, Mitchell PG, Libby P, Lee RT (1999) Matrix metalloproteinase inhibition attenuates early left ventricular enlargement after experimental myocardial infarction in mice. Circulation 99:3063-3070. https://doi.org/10.1161/01. cir.99.23.3063

19. Peterson JT (2004) Matrix metalloproteinase inhibitor development and the remodeling of drug discovery. Heart Fail Rev 9:63-79. https://doi.org/10.1023/B:HREV.0000011395.11179.af

20. Nagase H, Woessner JF (1999) Matrix metalloproteinases. J Biol Chem 274:21491-21494. https://doi.org/10.1074/ jbc.274.31.21491

21. Griffin MO, Fricovsky E, Ceballos G, Villarreal F (2010) Tetracyclines: a pleitropic family of compounds with promising therapeutic properties. Review of the literature. Am J Physiol Cell Physiol 299:C539-C548. https://doi.org/10.1152/ajpcell.00047.2010

22. Park JL, Lucchesi BR (1999) Mechanisms of myocardial reperfusion injury. Ann Thorac Surg 68:1905-1912. https://doi. org/10.1016/s0003-4975(99)01073-5

23. Kraus RL, Pasieczny R, Lariosa-Willingham K, Turner MS, Jiang A, Trauger JW (2005) Antioxidant properties of minocycline: neuroprotection in an oxidative stress assay and direct radicalscavenging activity. J Neurochem 94:819-827. https://doi.org/10 $.1111 / j .1471-4159.2005 .03219 . x$

24. Forloni G, Iussich S, Awan T, Colombo L, Angeretti N, Girola L, Bertani I, Poli G, Caramell M, Grazia Bruzzone M, Farina L, Limido L, Rossi G, Giaccone G, Ironside JW, Bugiani O, Salmona M (2002) Tetracyclines affect prion infectivity. Proc Natl Acad Sci USA 99:10849-10854. https://doi.org/10.1073/pnas.162195499

25. Saelens X, Festjens N, Vande Walle L, van Gurp M, van Loo G, Vandenabeele $\mathrm{P}$ (2004) Toxic proteins released from mitochondria in cell death. Oncogene 23:2861-2874. https://doi.org/10.1038/ sj.onc. 1207523

26. Thorburn A (2004) Death receptor-induced cell killing. Cell Signal 16:139-144. https://doi.org/10.1016/j.cellsig.2003.08.007

27. Yrjänheikki J, Keinänen R, Pellikka M, Hökfelt T, Koistinaho J (1998) Tetracyclines inhibit microglial activation and are neuroprotective in global brain ischemia. Proc Natl Acad Sci USA 95:15769-15774. https://doi.org/10.1073/pnas.95.26.15769

28. Sanchez Mejia RO, Ona VO, Li M, Friedlander RM (2001) Minocycline reduces traumatic brain injury-mediated caspase-1 activation, tissue damage, and neurological dysfunction. Neurosurgery 48:1393-1399. https://doi.org/10.1097/00006123-20010 6000-00051

29. Du Y, Ma Z, Lin S, Dodel RC, Gao F, Bales KR, Triarhou LC, Chernet E, Perry KW, Nelson DL, Luecke S, Phebus LA, Bymaster FP, Paul SM (2001) Minocycline prevents nigrostriatal dopaminergic neurodegeneration in the M.PTP model of Parkinson's disease. Proc Natl Acad Sci USA 98:14669-14674. https://doi. org/10.1073/pnas.251341998

30. Chen M, Ona VO, Li M, Ferrante RJ, Fink KB, Zhu S (2000) Minocycline inhibits caspase- 1 and caspase- 3 expression and delays mortality in a transgenic mouse model of Huntington disease. Nat Med. https://doi.org/10.1038/77528

31. Wang X, Zhu S, Drozda M, Zhang W, Stavrovskaya IG, Cattaneo E, Ferrante RJ, Kristal BS, Friedlander RM (2003) Minocycline inhibits caspase-independent and -dependent mitochondrial cell death pathways in models of Huntington's disease. Proc Natl Acad Sci USA 100:10483-10487. https://doi.org/10.1073/pnas.18325 01100

32. Pruzanski W, Greenwald RA, Street IO, La-leberte F, Stefanski E, Vadas P (1992) Inhibition of enzymatic activity of phospholipase A2 by minocycline and doxycycline. Biochem Pharmacol 44:1165-1170. https://doi.org/10.1016/0006-2952(92)90381-r
33. Esterly NB, Koransky JS, Furey NL, Trevisan M (1984) Neutrophil chemotaxis in patients with acne receiving oral tetracycline therapy. Arch Dermatol 120:1308-1313

34. Gable WL, Tsukuda N (1991) The influence of divalent cations and doxycycline on iodoacetamide-inhibitable leukocyte adherence. Res Commun Chem Pathol Pharmacol 74:131-140

35. Thong YH, Ferrante A (1979) Inhibition of mitogen-induced human lymphocyte proliferative responses by tetracycline analogues. Clin Exp Immunol 35:443-446

36. Ataie-Kachoie P, Badar S, Morris DL, Pourgholami MH (2013) Signal transduction minocycline targets the NF-kB nexus through suppression of TGF-b1-TAK1-IkB signaling in Ovarian cancer. Mol Cancer Res 11:1279-1291. https://doi. org/10.1158/1541-7786.MCR-13-0239

37. Sun J, Shigemi H, Tanaka Y, Yamauchi T, Ueda T, Iwasaki $\mathrm{H}$ (2015) Tetracyclines downregulate the production of LPSinduced cytokines and chemokines in THP-1 cells via ERK, $\mathrm{p} 38$, and nuclear factor- $\mathrm{\kappa B}$ signaling pathways. Biochem Biophy Rep 4:397-404. https://doi.org/10.1016/j.bbrep.2015.11.003

38. Negrette A (1960) Encefalitis epidémica. Invest Clin 1:13-34

39. Negrette A, Mosquera J (1974) Epidemia de encefalitis de 1959 en Maracaibo (San Francisco), Estado Zulia, Venezuela. Manifestaciones clínicas y terapéutica antibiótica. Invest Clin 15:11-44

40. Negrette A, Maso-Dominguez J, Rolling CL (1964) Mononucleosis Infecciosa epidémica. Invest Clin 5:49-53

41. Negrette A (1968a) Encefalitis equina venezolana. Leucocitos vacuolados. Invest Clin 26:97-107

42. Negrette A (1968b) Parálisis facial y tetraciclina. Invest Clin 26:5-6

43. Negrette A (1980) Tetraciclina y virus pequeños. Editorial. Invest Clin 21:235-238

44. Negrette A (1990) Tetraciclina y Sida. Invest Clin 31:117-119

45. Negrette A, Hernandez H (1974) Therapeutic effect of tetracycline in the experimental venezuelan encephalitis. Invest Clin 15:45-51

46. Negrette A, Escalona A, Ryder S (1970) Acción de la tetraciclina sobre la encefalitis aenezolana experimental. Comunicacion preliminar. Invest Clin 36:7-11

47. Lemaitre M, Guetard D, Henin Y, Montagnier L, Zerial A (1990) Protective activity of tetracycline analogs against the cytopathic effect of the human immunodeficiency viruses in CEM cells. Res Virol 141:5-16. https://doi.org/10.1016/0923-2516(90)90052-k

48. Si Q, Cosenza M, Kim MO, Zhao ML, Brownlee M, Goldstein $\mathrm{H}$ (2004) A novel action of minocycline: inhibition of human immunodeficiency virus type 1 infection in microglia. J Neurovirol 10:284-292. https://doi.org/10.1080/13550280490499533

49. Zink MC, Uhrlaub J, DeWitt J, Voelker T, Bullock B, Mankowski J (2005) Neuroprotective and anti-human immunodeficiency virus activity of minocycline. JAMA 293:2003-2011. https://doi. org/10.1001/jama.293.16.2003

50. Follstaedt SC, Barber SA, Zink MC (2008) Mechanisms of minocycline-induced suppression of simian immunodeficiency virus encephalitis: inhibition of apoptosis signal-regulating kinase 1 . J Neurovirol 14:376-388. https://doi.org/10.1080/1355028080 2199898

51. Jenwitheesuk E, Samudrala R (2007) Identification of potential HIV-1 targets of minocycline. Bioinformatics 23:2797-2799. https://doi.org/10.1093/bioinformatics/btm424

52. Michaelis M, Kleinschmidt MC, Doerr HW, Cinat J (2007) Minocycline inhibits West Nile virus replication and apoptosis in human neuronal cells. J Antimicrob Chemother 60:981-986. https://doi.org/10.1093/jac/dkm307

53. Mishra MK, Basu A (2008) Minocycline neuroprotects, reduces microglial activation, inhibits caspase 3 induction, and viral replication following Japanese encephalitis. J Neurochem 105:15821595. https://doi.org/10.1111/j.1471-4159.2008.05238.x 
54. Lai YC, Chuang YC, Chang CP, Lin YS, Perng GC, Wu HC, Hsieh SL, Yeh TM (2018) Minocycline suppresses dengue virus replication by down-regulation of macrophage migration inhibitory factor-induced autophagy. Antiviral Res 155:28-38. https:// doi.org/10.1016/j.antiviral.2018.05.002

55. Quick ED, Seitz S, Clarke P, Tyler KL (2017) Minocycline has anti-inflammatory effects and reduces cytotoxicity in an Ex Vivo spinal cord slice culture model of west Nile virus infection. J Virol 91:e0569-e1517. https://doi.org/10.1128/JVI.00569-17

56. Irani DN, Prow NA (2007) Neuroprotective interventions targeting detrimental host immune responses protect mice from fatal alphavirus encephalitis. J Neuropathol Exp Neurol 66:533-544. https://doi.org/10.1097/01.jnen.0000263867.46070.e2

57. Valero N, Mosquera J, Alcocer S, Bonilla E, Salazar J, ÁlvarezMon M (2015) Melatonin, minocycline and ascorbic acid reduce oxidative stress and viral titers and increase survival rate in experimental Venezuelan equine encephalitis. Brain Res 1622:368-376. https://doi.org/10.1016/j.brainres.2015.06.034

58. Bawage SS, Tiwari PM, Pillai S, Dennis VA, Singh SR (2019) Antibiotic minocycline prevents respiratory syncytial virus infection. Viruses 11:1-10. https://doi.org/10.3390/v11080739

59. Liao YT, Wang SM, Chen SH (2019) Anti-inflammatory and antiviral effects of minocycline in enterovirus 71 infections. Biomed Pharmacother 118:109271. https://doi.org/10.1016/j. biopha.2019.109271

60. Sharifi A, Amanlou A, Moosavi-Movahedi F, Golestanian S, Amanlou M (2017) Tetracyclines as a potential antiviral therapy against Crimean Congo hemorrhagic fever virus: docking and molecular dynamic studies. Comput Biol Chem 70:1-6. https:// doi.org/10.1016/j.compbiolchem.2017.06.003

61. Takaoka A, Hayakawa S, Yanai H (2003) Integration of interferon alpha/beta signalling to $\mathrm{p} 53$ responses in tumour suppression and antiviral defence. Nature 424:516-523. https://doi.org/10.1038/ nature 01850

62. Turpin E, Luke K, Jone J (2005) Influenza virus infection increases p53 activity: role of p53 in cell death and viral replication. J Virol 79:8802-8811. https://doi.org/10.1128/JVI.79.14.8802-8811.2005

63. Fujioka S, Schmidt C, Sclabas GM, Li Z, Pelicano H, Peng B, Yao A, Niu J, Zhang W, Evans DB, Abbruzzese JL, Huang P, Chiao PJ (2004) Stabilization of $\mathrm{p} 53$ is a novel mechanism for proapoptotic function of NF-кB. J Biol Chem 279:27549-27559. https://doi. org/10.1074/jbc.M313435200

64. Wu ZC, Wang X, Wei JC, Li BB, Shao DH, Li YM, Liu K, Shi YY, Zhou B, Qiu YF, Ma ZY (2015) Antiviral activity of doxycycline against vesicular stomatitis virus in vitro. FEMS Microbiol Lett 362:fnv195. https://doi.org/10.1093/femsle/fnv195

65. Li Y, Wu Z, Liu K, Qi P, Xu J, Wei J, Li B, Shao D, Shi Y, Qiu Y, Ma Z (2017) Doxycycline enhances adsorption and inhibits early-stage replication of porcine reproductive and respiratory syndrome virus in vitro. FEMS Microbiol Lett 364:1-6. https:// doi.org/10.1093/femsle/fnx 170

66. Ng HH, Narasaraju T, Phoon MC, Sim MK, Seet JE, Chow VT (2012) Doxycycline treatment attenuates acute lung injury in mice infected with virulent influenza $\mathrm{H} 3 \mathrm{~N} 2$ virus: involvement of matrix metalloproteinases. Exp Mol Pathol 92:287-295. https ://doi.org/10.1016/j.yexmp.2012.03.003

67. Rothan HA, Bahrani H, Mohamed Z, Teoh TC, Shankar EM, Rahman NA, Yusof R (2015) A combination of doxycycline and ribavirin alleviated chikungunya infection. PLoS ONE 10:e0126360. https://doi.org/10.1371/journal.pone.0126360

68. Rothan HA, Buckle MJ, Ammar YA, Mohammadjavad P, Shatrah O, Noorsaadah AR, Rohana Y (2013) Study the antiviral activity of some derivatives of tetracycline and non-steroid anti-inflammatory drugs towards dengue virus. Trop Biomed 30:681-690

69. Rothan HA, Mohamed Z, Paydar M, Rahman NA, Yusof R (2014) Inhibitory effect of doxycycline against dengue virus replication in vitro. Arch Virol 159:711-718. https://doi.org/10.1007/s0070 5-013-1880-7

70. Yang JM, Chen YF, Tu YY, Yen KR, Yang YL (2007) Combinatorial computational approaches to identify tetracycline derivatives as flavivirus inhibitors. PLoS ONE 2:e428. https://doi. org/10.1371/journal.pone.0000428

71. Speer BS, Shoemaker NB, Salyers AA (1992) Bacterial resistance to tetracycline: mechanisms, transfer, and clinical significance. Clin Microbiol Rev 5(4):387-399. https://doi.org/10.1128/ cmr.5.4.387

72. Zakeri B, Wright GD (2008) Chemical biology of tetracycline antibiotics. Biochem Cell Biol 86:124-136. https://doi. org/10.1139/O08-002

73. Humar A, McGilvray I, Phillips MJ, Levy GA (2004) Severe acute respiratory syndrome and the liver. Hepatology 39:291-294. https ://doi.org/10.1002/hep.20069

74. Wang J (2020) Fast identification of possible drug treatment of coronavirus disease-19 (COVID-19) through computational drug repurposing study. J Chem Inf Model. https://doi.org/10.1021/acs. jcim.0c00179 (Online ahead of print)

75. Sargiacomo C, Sotgia F, Lisanti MP (2020) COVID-19 and chronological aging: senolytics and other anti-aging drugs for the treatment or prevention of corona virus infection? Aging (Albany NY) 12:6511-6517. https://doi.org/10.18632/aging.103001

76. Sodhi M, Etminan M (2020) Therapeutic potential for tetracyclines in the treatment of COVID-19. Pharmacotherapy 40:487488. https://doi.org/10.1002/phar.2395

77. Song H, Fares M, Maguire KR, Sidén A, Potácová Z (2014) Cytotoxic effects of tetracycline analogues (doxycycline, minocycline and COL-3) in acute myeloid leukemia HL-60 cells. PLoS ONE 9:e114457. https://doi.org/10.1371/journal.pone.0114457

78. Ruiz-Moreno C, Velez-Pardo C, Jimenez-Del-Rio M (2018) Minocycline induces apoptosis in acute lymphoblastic leukemia Jurkat cells. Toxicol In Vitro 50:336-346. https://doi.org/10.1016/j. tiv.2018.03.012

79. O’Brien V (1998) Viruses and apoptosis. J Gen Virol 79:18331845. https://doi.org/10.1099/0022-1317-79-8-1833

80. Ren Y, Shu T, Wu D, Mu J, Wang C, Huang M, Han Y, Zhang XY, Zhou W, Qiu Y, Zhou X (2020) The ORF3a protein of SARSCoV-2 induces apoptosis in cells. Cell Mol Immunol 18:1-3. https ://doi.org/10.1038/s41423-020-0485-9

81. Bangladesh Medical Research Council (BMRC) (2020) Efficacy and Safety of Ivermectin and Doxycycline in Combination or IVE Alone in Patients With COVID-19 Infection. ClinicalTrials.gov Identifier: NCT04407130. NIH. U.S. National Library of Medicine

82. Wu F, Zhao S, Yu B, Chen YM, Wang W, Song ZG, Hu Y, Tao ZW, Tian JH, Pei YY, Yuan ML, Zhang YL, Dai FH, Liu Y, Wang QM, Zheng JJ, Xu L, Holmes EC, Zhang YZ (2020) A new coronavirus associated with human respiratory disease in China. Nature 579:365-369. https://doi.org/10.1038/s41586-020-2008-3

Publisher's Note Springer Nature remains neutral with regard to jurisdictional claims in published maps and institutional affiliations. 